\title{
Cloning and sequencing of the virulent gene LipL32 of Leptospira interrogans serovar Autumnalis
}

\author{
Sriram Vamshi Krishna, Siju Joseph, R Ambily, M Mini, Liya Anto and Sheethal G Mohan \\ Department of Veterinary Microbiology, \\ College of Veterinary and Animal Sciences, Kerala Veterinary and Animal Sciences University, Mannuthy, Kerala, India \\ Corresponding author: Vamshi Krishna Sriram, email:vkvamshi1@gmail.com \\ Received: 14-08-2012, Accepted: 03-09-2012, Published online: 19-01-2013
}

How to cite this article: Krishna SV, J oseph S, Ambily R, Mini M, Anto L and Mohan SG (2013) Cloning and sequencing of the virulent gene LipL32 of Leptospira interrogans serovar Autumnalis, Vet. World 6(4): 193-195, doi: 10.5455/vetworld.2013. 193-195

\begin{abstract}
Aim: To clone the virulent gene LipL32 of Leptospira interrogans serovar Autumnalis and to analyze the sequence with LipL32 gene of other pathogenic serovars of Leptopsira.

Materials and Methods: Leptospira interrogans serovar Autumnalis procured from Leptospira research laboratory, Chennai was used in the study. Polymerase chain reaction (PCR) was carried out for amplifying LipL32 gene using the reported primers of Leptospira Kirschnerii. The PCR product was cloned into TA cloning vector and the vector was transformed into E.Coli DH5 $\alpha$ cells. The plasmid was isolated from E.Coli and sent for sequencing with universal primers. The sequence was submitted in genbank with accession number JQ861883.
\end{abstract}

Results: The PCR product revealed an amplicon of 790 bp. The LipL32 gene sequence of Leptospira interrogans serovar Autumnalis showed $99 \%$ similarity with most of the pathogenic Leptospires.

Conclusions: LipL32 gene of Leptospira is highly conserved in most of the pathogenic Leptospires. The study concludes that this gene could be used as a target for the diagnosis of leptospirosis in animals and humans and could be tested as an important candidate antigen for vaccine production.

Keywords: cloning, sequencing, LipL32 gene, Leptospira Autumnalis

\section{I ntroduction}

Leptospirosis has re-emerged as an important zoonotic disease in India and is endemic in most of the southern states like Kerala, Tamil Nadu and certain parts of Andhra Pradesh [1-3]. Conventional methods of diagnosis like demonstration of organisms by dark field microscopy, isolation are less sensitive and Microscopic agglutination test, the gold standard test can be performed only in reference laboratories since it requires the maintenance of live cultures. The tests employing outer membrane proteins (OMPs) showed high sensitivity and specificity $[4,5]$. The results of recombinant OMP antigen based enzyme linked immunosorbant assay's (ELISA) are promising [6]. LipL32 was consistently observed in all pathogenic leptospires and was observed to be the immunodominant protein antigen recognized by the human humoral response during natural infections. This protein could be useful as a marker of infection for laboratory case confirmation in the field and in differentiating leptospirosis from other causes of acute febrile illness [7]. Leptospiral protein p32 is the most immunodominant protein and could be employed for the development of novel diagnostic assays [8]. The present study was carried out to clone and sequence the LipL32 gene of Leptospira interrogans serovar Autumnalis and to analyze the sequence relationship with other pathogenic leptospires.

\section{Materials and Methods}

Leptospira interrogans serovar Autumnalis, procured form Leptospira research centre, Tamil Nadu Veterinary and Animal Sciences University, Chennai and maintained in the Department of Veterinary Microbiology, College of Veterinary and Animal Sciences, Mannuthy was used in the study. The organisms were maintained in Ellinghausen-McCullough-JohnsonHarris medium (EMJH) (Difco) supplemented with bovine albumin and sub cultured at seven days interval. E.coli DH5 $\alpha$ was maintained in Luria-Bertani agar (HiMedia, Mumbai). The genomic DNA of Leptospira was extracted as per the method described [9]. The PCR was carried out using the reported primers of LipL32 gene. The primer sequences were 5' - CGC GCT GCA GTT ACT TAG TCG CGT CA G AAG- 3' and 5'- CGC GGT CGA CGC TTT CGG TGG TCT CTG CCA AGC - 3' [11]. The primers were diluted in nuclease free water so as to have a final concentration of $20 \mathrm{pmol} / \mu \mathrm{l}$. The reaction was carried out in a $25 \mu \mathrm{l}$ reaction mixture, containing $10 \mathrm{X}$ PCR buffer with $\mathrm{MgCl}_{2}, 10 \mathrm{mM}$ dNTP mix, 20 pmol of each primer, 1.0 $\mathrm{U}$ of Taq DNA polymerase, nuclease free water and template DNA. The PCR progamme was standardized with one cycle of initial denaturation at $94^{\circ} \mathrm{C}$ for $4 \mathrm{~min}$ followed by 30 cycles each of denaturation $\left(94^{\circ} \mathrm{C}\right.$ for $45 \mathrm{sec}$, annealing $\left(54^{\circ} \mathrm{C}\right.$ for $\left.45 \mathrm{sec}\right)$ and extension $\left(72^{\circ}\right.$ $\mathrm{C}$ for $45 \mathrm{sec})$ and final extension $\left(72^{\circ} \mathrm{C}\right.$ for $\left.5 \mathrm{~min}\right)$. The PCR product thus obtained was analyzed by running on $1.0 \%$ agarose gel. The gel was visualized under UV transilluminator and the results were documented in a gel documentation system (Alpha Innnotech Corporation, 
Table-1. Results of nucleotide Blast showing similarity of LipL 32 gene of Leptospira interrogans serovar Autumnalis with other pathogenic serovars

\begin{tabular}{|c|c|c|c|c|c|c|}
\hline S.No & $\begin{array}{l}\text { Accession } \\
\text { number }\end{array}$ & Description & $\begin{array}{l}\text { Max } \\
\text { score }\end{array}$ & $\begin{array}{l}\text { Total } \\
\text { score }\end{array}$ & $\begin{array}{l}\text { Query } \\
\text { coverage }\end{array}$ & $\begin{array}{r}\text { Max } \\
\text { indent }\end{array}$ \\
\hline 1 & EU526391 & $\begin{array}{l}\text { Leptospira interrogans serovar Autumnalis strain N2 } \\
\text { outermembrane lipoprotein LipL32 gene, partial cds }\end{array}$ & 1322 & 1322 & $96 \%$ & $100 \%$ \\
\hline 2 & AY568679 & $\begin{array}{l}\text { Leptospira interrogans strain Lai major outer membrane } \\
\text { protein (lipL32) gene, complete cds }\end{array}$ & 1336 & 1336 & $96 \%$ & $100 \%$ \\
\hline 3 & JQ013520 & $\begin{array}{l}\text { Leptospira interrogans serovar Balico major outer } \\
\text { membrane lipoprotein LipL32 (lipL32) gene, partial cds }\end{array}$ & 1341 & 1341 & $98 \%$ & $99 \%$ \\
\hline 4 & AY609327 & $\begin{array}{l}\text { Leptospira interrogans serovar Grippotyphosa major outer } \\
\text { membrane protein (lipl32) gene, complete cds }\end{array}$ & 1339 & 1339 & $97 \%$ & $99 \%$ \\
\hline 5 & AY609325 & $\begin{array}{l}\text { Leptospira interrogans serovar Australis major outer } \\
\text { membrane protein (lipl32) gene, complete cds }\end{array}$ & 1339 & 1339 & $97 \%$ & $99 \%$ \\
\hline 6 & AY609321 & $\begin{array}{l}\text { Leptospira interrogans serovar Canicola major outer } \\
\text { membrane protein (lipl32) gene, complete cds }\end{array}$ & 1339 & 1339 & $97 \%$ & $99 \%$ \\
\hline 7 & AE016823 & $\begin{array}{l}\text { Leptospira interrogans serovar Copenhageni str. Fiocruz } \\
\text { L1-130, chromosome I, complete sequence }\end{array}$ & 1339 & 1339 & $97 \%$ & $99 \%$ \\
\hline 8 & GU592525 & $\begin{array}{l}\text { Leptospira interrogans serovar Hardjo hemolysis- } \\
\text { associated protein I (hapl) gene, complete cds }\end{array}$ & 1334 & 1334 & $97 \%$ & $99 \%$ \\
\hline 9 & GU183106 & $\begin{array}{l}\text { Leptospira interrogans serovar Icterohaemorrhagiae strain } \\
\text { RGA hemolysis associated protein I (hapl) gene, complete cds }\end{array}$ & 1334 & 1334 & $97 \%$ & $99 \%$ \\
\hline 10 & AY609328 & $\begin{array}{l}\text { Leptospira interrogans serovar Hebdomadis major outer } \\
\text { membrane protein (lipl32) gene, complete cds }\end{array}$ & 1334 & 1334 & $97 \%$ & $99 \%$ \\
\hline 11 & AY609326 & $\begin{array}{l}\text { Leptospira noguchii serovar Pomona major outer membrane } \\
\text { protein (lipl32) gene, complete cds }\end{array}$ & 1334 & 1334 & $97 \%$ & $99 \%$ \\
\hline 12 & AY609333 & $\begin{array}{l}\text { Leptospira borgpetersenii serovar Mini major outer membrane } \\
\text { protein (lipl32) gene, complete cds }\end{array}$ & 1328 & 1328 & $97 \%$ & $99 \%$ \\
\hline 13 & AY461917 & $\begin{array}{l}\text { Leptospira kirschneri strain } 5621 \text { LipL32 (lipL32) gene, } \\
\text { partial cds }\end{array}$ & 1317 & 1317 & $97 \%$ & $99 \%$ \\
\hline
\end{tabular}

USA). The PCR product was gel eluted using GeneAll DNA purification kit as per the manufacturer protocol (GeneAll, Korea). The cloning vector pTZ57R/T was used for cloning the purified DNA as per the method described by the manufacturer (Fermentas). The cloning vector was transformed into $E$. coli $\mathrm{DH} 5 \alpha$ cells and the culture was plated on Luria-Bertani (LB) agar plates containing ampicillin $(100 \mu \mathrm{g} / \mathrm{ml})$, with the help of sterile L-spreader and incubated at $37^{\circ} \mathrm{C}$ overnight. The obtained colonies were subjected to PCR and the confirmed colonies were inoculated into LB broth containing ampicillin at $37^{\circ} \mathrm{C}$ overnight in a shaker incubator for plasmid isolation. The plasmid was extracted by alkaline lysis method using GeneAll plasmid extraction kit as per the manufacturers protocol (GeneAll, Korea). The plasmid was reconfirmed by PCR before sending for sequencing. The plasmid was sequenced using universal M13 forward and reverse primers (SciGenom labs Pvt. Ltd, Cochin, Kerala). The vector sequence was removed using Vecscreen tool and the trimmed sequence was submitted to NCBI GenBank (accession no. JQ861883). Further, the nucleotide sequence was subjected to nucleotide BLAST to compare for sequence similarities with other sequences available in the NCBI database (http:// blast.ncbi.nl.nih.gov).

\section{Results and Discussion}

The extracted genomic DNA from Leptospira interrogans serovar Autumnalis showed an Optical Density of 1.7 indicating the purity of isolated DNA. The PCR amplification of LipL32 gene revealed an amplicon of $790 \mathrm{bp}$ on $1.0 \%$ agarose gel (Fig-1 ). The sequence was deposited in the nucleotide GenBank under the accession no. JQ861883. The sequence when subjected to nucleotide BLAST search revealed a high degree of similarity with other pathogenic serovars of Leptospira (Table-1). The LipL32 gene is highly conserved in most of the pathogenic serovars of Leptospira as evidenced from the sequence analysis. The obtained sequences shown $100 \%$ similarity with LipL32 gene sequences of Leptospira interrogans serovar Autumnalis (EU526391) and Leptospira interrogans serovar Lai (AY568679) and 99\% similarity with Leptospira interrogans serovars Balico (JQ013520), Grippotyphosa (AY609327), Australis (AY609325), Canicola (AY609321), Copenhageni (AE016823), hardjo (GU592525), Icterohaemorrhagiae (GU183106) and Hebdomadis (AY609328), Leptospira noguchii serovar Pomona (AY609326), Leptospira borgpetersenii serovar Mini (AY609333) and Leptospira kirschneri (AY461917). LipL32 protein is the most abundant and an important surface protein present only in pathogenic Leptospira and found to play a major role in host immunogenic response and in infection [10]. The LipL32 gene of Leptospira interrogans serovar Sejroe was found to be conserved in many pathogenic serovars [11] which is in agreement with the present study. Similar findings were reported by several other workers [12]. The utility of LipL32 for diagnosis of leptospirosis in animals and humans has been documented widely [13-15].

\section{Conclusion}

The present study concludes that the similarity in the sequences of the cloned product with other pathogenic serovars, suggests its importance in the utility of LipL32 gene as an important target for the diagnosis of leptospirosis in animals and humans as well as promising vaccine candidate as the protein is reported to be immunodominant. 


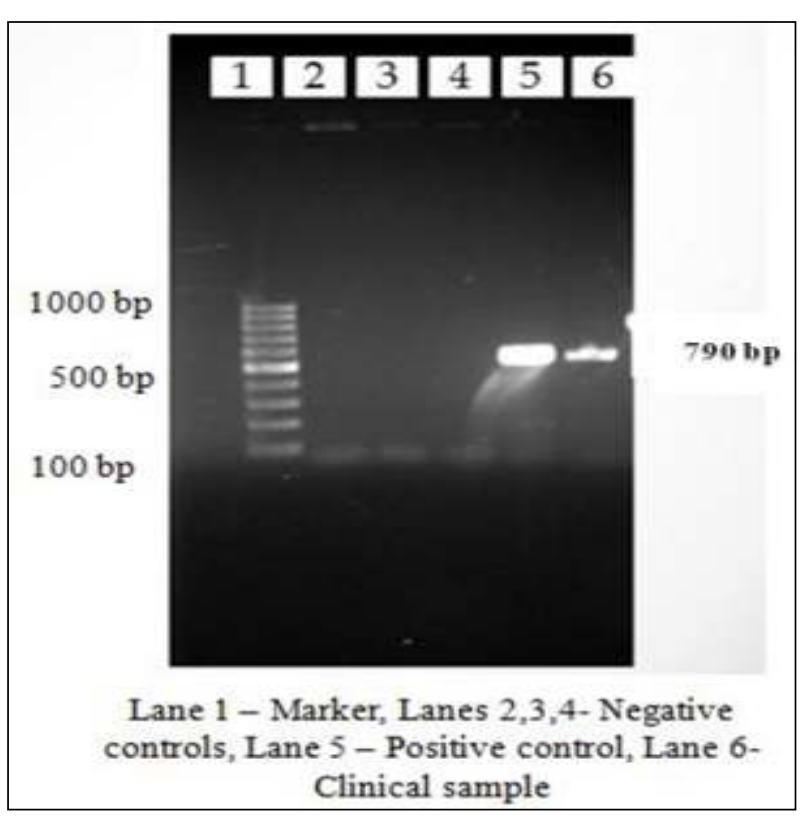

\section{Author's contribution}

SVK, SJ and RA implemented the study design and carried out the work. All other authors were involved in scientific discussion and analysis of the data. All authors drafted and revised the manuscript. All authors read and approved the final manuscript.

\section{Acknowledgements}

The authors thank the Director, Leptospira research laboratory, Chennai for providing the culture and Dean, College of Veterinary and Animal Sciences, Mannuthy for providing the facilities for carrying out the work.

\section{Competing interests}

Authors declare that they have no competing interests.

\section{References}

1. Koteeswaran, A. (2006) Seroprevalence of leptospirosis in man and animals in Tamil Nadu, Indian J. Med. Microbiol. 24: 329-331.

2. Balakrishnan, G., Govindarajan, R., Meenambigai, T. V., Jayakumar, V. and Manohar, M. B. (2008) Seroprevalence of animal leptospirosis in certain parts of Tamil Nadu, Indian Vet. J. 85:227-228.

3. Abhinay, G., Joseph, S. and Ambily, R. (2012) Seroprevalence of canine leptospirosis, Indian Vet. J. 89(2): 72-73.

4. Singh, A., Kumar, M. and Srivastava, S. K. (2004) Diagnostic utility of a dominant outer membrane protein of Leptospira borgpetersenii serovar Hardjo, Indian J. Comp. Microbiol. Immunol. Infect. Dis. 25:90-93.

5. Srivastava, S. K., Chaudhuri, P., Thangapandian, E., Mariya, R. and Amutha, R. (2006) Evaluation of recombinant Leptospira interrogans serovar Canicola outer membrane proteins as diagnostic antigen, Indian J. Med. Microbiol. 24: 346-348.
Figure-1. Amplification of LipL 32 gene by Polymerase chain reaction

6. Flannery, B., Costa, D., Carvalho, F. P., Guerreiro, H., Matsunaga, J., Silva, E. D. da, Ferreira, A. G. P., Riley, L. W., Reis, M. G., Haake, D. A. and Ko, A. I. (2001) Evaluation of recombinant Leptospira antigen-based enzyme-linked immunosorbent assays for the serodiagnosis of leptospirosis, J. Clin. Microbiol.39: 3303-3310.

7. Guerreiro, H., Croda, J., Flannery, B., Mazel, M., Matsunaga, J., Reis, M. G., Levett, P. N., Ko, A. I. and Haake, D. A. (2001) Leptospiral proteins recognized during the humoral immune response to leptospirosis in human, Infect. Immun. 69: 4958-4968.

8. Natarajaseenivasan, K., Vijayachari, P., Sugunan, A. P., Sharmaan, S. and Sehgal, S. C. (2004) Leptospiral proteins expressed during acute and convalescent phases of human leptospirosis, Indian J. Med. Res. 151-159.

9. Sambrook, J. and Russell, D. W. (2001) Molecular cloning: A laboratory manual. $3^{\text {rd }}$ edition. Cold Spring Harbor laboratory, Cold Spring Harbor, NY.

10. Hauk, P., Carvalho, E. and Ho, P. L. (2011) Expression and purification of the non-tagged LipL32 of pathogenic Leptospira, Braz. J. Med. Biol. Res. 44(4): 297-302.

11. Amutha, R., Chaudhary, P., Garg, A. P., Vasan, P., Cheema, P. S. and Srivastava, S. K. (2007) Cloning and sequence analysis of the gene encoding LipL32 of Leptospira interrogans serovar Sejroe, Vet. Res. Comm. 31: 513-519.

12. Dey, S., Mohan, C. M., Ramadass, P. and Nachimuthu, K. (2008) Diagnosis of leptospirosis by recombinant antigen based single serum dilution ELISA, Indian J. Med. Res. 128: 172-177.

13. Bomfim, M. R. S., Kob, A. and Koury, M. C. (2005) Evaluation of the recombinant LipL32 in enzyme-linked immunosorbent assays for the serodiagnosis of bovine leptosprirosis, Vet. Microbiol. 109: 89-94.

14. Ram, S., Vimalin, J. M., Jambulingam, M., Tiru, V., Gopalakrishnan, R, K. and Naraharirao, M. H. (2012) Mala. J. Microbiol. 8(1): 26-33.

15. Ahmed, S.A., Sandai, D.A., Musa, S., Hoe, C. H., Riadzi, M., Lau, K. L. and Tang, T. K. (2012) Rapid diagnosis of leptospirosis by multiplex PCR, Mala. J. Med. Sci. 19(3): 916. 